Brit. J. soc. Med. (1950), 4, 61-74

\title{
THE CARE OF THE CHRONIC SICK \\ II. SOCIAL AND DEMOGRAPHIC DATA
}

BY

\author{
C. R. LOWE and THOMAS McKEOWN
}

From the Department of Social Medicine, University of Birmingham

The transfer of responsibility for the care of the chronic sick in hospital from Local Authorities to Regional Hospital Boards has raised two important questions. First, Regional Hospital Boards have to decide on the location and number of beds to be provided for this class of patient. Their waiting lists indicate that more accommodation is needed, but more accommodation of the existing type would aggravate staffing difficulties which are already serious. The alternative possibility of catering for these patients in general hospitals has much to recommend it, but raises the objection that the apparent number of patients would prohibit the general application of such a policy. Second, Local Authorities have to agree on the interpretation of those sections of Part III of the National Health Services Act* (1946) and of Part III of the National Assistance Act $\dagger$ (1948), which refer to their responsibility for complementary facilities. The intention of the acts is evidently to leave to Local Authorities domiciliary and institutional care of persons who need not be admitted to hospitals, but the wording of the acts reflects the lack of information about the numbers and types of patients for whom Local Authorities will be expected to cater.

The fact that social as well as medical needs have in the past determined the admission and retention of patients in hospitals for the chronic sick suggested that the number of patients now in hospital is unreliable as a guide to future developments. Consideration of the medical, nursing, and social requirements of 1,005 patients in one hospital indicated that about three-fifths were not in need of hospital services and could have been cared for in their own homes or in institutions other than hospitals (Lowe and McKeown, 1949). One-fifth of the patients required institutional supervision because of their abnormal mental state, and only the remaining one-fifth were in need of services which could properly be considered the concern of general hospital authorities. Reduced to these dimensions, the problem of the chronic sick in hospital can be reconsidered in relation to the general hospitals.

In this paper we examine other data which have a bearing on the commitments of Regional Hospital Boards and Local Authorities.

Hospital Beds occupied by the Chronic Sick: Age Specific Rates

The report of the Ministry of Health for the year ended March 31, 1947, gives the number of beds occupied by chronic sick patients in England and Wales as 70,000 , or 1.66 per thousand of the total population of $42,939,000$ (RegistrarGeneral, 1948). The ministry report for the previous year included the following

\footnotetext{
* Sections 25 and 29.
} 
estimates for area requirements (beds per thousand of the population) based on a national survey of hospitals.*

\begin{tabular}{|c|c|c|}
\hline London & . & . \\
\hline Berks., Bucks., Oxon. & . & . \\
\hline Eastern Area & & \\
\hline East Midlands & & .. \\
\hline Yorkshire $\quad \ldots \quad$. & & .. \\
\hline South Western Area & $\cdots$ & . \\
\hline South Wales .. & .. & \\
\hline
\end{tabular}

These figures were not obtained from uniform calculations and can only be accepted as rough assessments of local requirements, adjusted in some cases to allow for probable age changes in the population. Patients with chronic diseases in general hospitals, in mental and other special hospitals, and in their own homes, were of course excluded from the surveys and from the indices based on them. It is on the strength of these estimates that the ministry has put future bed requirements for the chronic sick at $2 \cdot 0$ to $2 \cdot 5$ per thousand of the population.

Similar estimates can be made for Birmingham, since two Birmingham hospitals, Western Road Infirmary and Selly Oak Hospital, draw their patients almost entirely from the City of Birmingham and are the only hospitals for the chronic sick in the city. Together they accommodated 1,515 patients at December 31, 1948,

TABLE I

Percentage Age and Sex Distribution of Patients in Western Road Infirmary $\dagger$

\begin{tabular}{|c|c|c|c|c|c|c|c|c|c|c|c|}
\hline Age (years) & . . & . & $20-29$ & $30-39$ & $40-49$ & $50-59$ & $60-69$ & $70-79$ & $80-89$ & $\begin{array}{l}90 \text { and } \\
\text { over }\end{array}$ & Totals \\
\hline Males. . & . & $\cdots$ & $\begin{array}{l}0 \cdot 2 \\
(1)\end{array}$ & $\begin{array}{l}0.9 \\
(4)\end{array}$ & $\begin{array}{l}3 \cdot 1 \\
(14)\end{array}$ & $\begin{array}{l}6 \cdot 2 \\
(28)\end{array}$ & $\begin{array}{l}21 \cdot 3 \\
(97)\end{array}$ & $\begin{array}{l}43 \cdot 6 \\
(198)\end{array}$ & $\begin{array}{l}22 \cdot 7 \\
(104)\end{array}$ & $\begin{array}{l}2 \cdot 0 \\
(9)\end{array}$ & $\begin{array}{c}100 \\
(455)\end{array}$ \\
\hline Females & . & . & $\begin{array}{l}0 \cdot 4 \\
(2)\end{array}$ & $\begin{array}{l}0 \cdot 4 \\
(2)\end{array}$ & $\begin{array}{l}2 \cdot 7 \\
(15)\end{array}$ & $\begin{array}{l}3 \cdot 3 \\
(18)\end{array}$ & $\begin{array}{l}16 \cdot 7 \\
(92)\end{array}$ & $\begin{array}{l}39 \cdot 8 \\
(219)\end{array}$ & $\begin{array}{l}31 \cdot 6 \\
(174)\end{array}$ & $\begin{array}{l}5 \cdot 1 \\
(28)\end{array}$ & $\begin{array}{c}100 \\
(550)\end{array}$ \\
\hline All patients & . & & $\begin{array}{l}0 \cdot 3 \\
(3)\end{array}$ & $\begin{array}{l}0 \cdot 6 \\
(6)\end{array}$ & $\begin{array}{l}2 \cdot 9 \\
(29)\end{array}$ & $\begin{array}{l}4 \cdot 6 \\
(46)\end{array}$ & $\begin{array}{c}18 \cdot 8 \\
(189)\end{array}$ & $\begin{array}{l}41 \cdot 5 \\
(417)\end{array}$ & $\begin{array}{l}27 \cdot 6 \\
(278)\end{array}$ & $\begin{array}{l}3 \cdot 7 \\
(37)\end{array}$ & $\begin{array}{c}100 \\
(1,005)\end{array}$ \\
\hline
\end{tabular}

TABLE II

Percentage Age and Sex Distribution of Chronic Sick Patients in Selly Oak Hospital $\dagger$

\begin{tabular}{|c|c|c|c|c|c|c|c|c|c|c|c|}
\hline Age (years) & . & $\ldots$ & $20-29$ & $30-39$ & $40-49$ & $50-59$ & $60-69$ & $70-79$ & $80-89$ & $\begin{array}{l}90 \text { and } \\
\text { over }\end{array}$ & Totals \\
\hline Males. . & . & $\cdots$ & $\begin{array}{l}2 \cdot 7 \\
(4)\end{array}$ & $\begin{array}{l}4 \cdot 1 \\
(6)\end{array}$ & $\begin{array}{l}7 \cdot 5 \\
(11)\end{array}$ & $\begin{array}{l}11 \cdot 0 \\
(16)\end{array}$ & $\begin{array}{c}23 \cdot 3 \\
(34)\end{array}$ & $\begin{array}{l}34 \cdot 9 \\
(51)\end{array}$ & $\begin{array}{l}15 \cdot 1 \\
(22)\end{array}$ & $\begin{array}{l}1 \cdot 4 \\
(2)\end{array}$ & $\begin{array}{c}100 \\
(146)\end{array}$ \\
\hline Females & . & $\cdots$ & $\begin{array}{l}0 \cdot 8 \\
(3)\end{array}$ & $\begin{array}{l}1 \cdot 4 \\
(5)\end{array}$ & $\begin{array}{l}3 \cdot 9 \\
(14)\end{array}$ & $\begin{array}{l}10 \cdot 4 \\
(38)\end{array}$ & $\begin{array}{l}14 \cdot 0 \\
(51)\end{array}$ & $\begin{array}{l}34 \cdot 6 \\
(126)\end{array}$ & $\begin{array}{l}30 \cdot 2 \\
(110)\end{array}$ & $\begin{array}{l}4 \cdot 7 \\
(17)\end{array}$ & $\begin{array}{l}100 \\
(364)\end{array}$ \\
\hline All patients & . & $\cdots$ & $\begin{array}{l}1 \cdot 4 \\
(7)\end{array}$ & $\begin{array}{l}2 \cdot 1 \\
(11)\end{array}$ & $\begin{array}{l}4 \cdot 9 \\
(25)\end{array}$ & $\begin{array}{l}10 \cdot 6 \\
(54)\end{array}$ & $\begin{array}{l}16 \cdot 7 \\
(85)\end{array}$ & $\begin{array}{l}34 \cdot 7 \\
(177)\end{array}$ & $\begin{array}{l}25 \cdot 9 \\
(132)\end{array}$ & $\begin{array}{l}3 \cdot 7 \\
(19)\end{array}$ & $\begin{array}{c}100 \\
(510)\end{array}$ \\
\hline
\end{tabular}



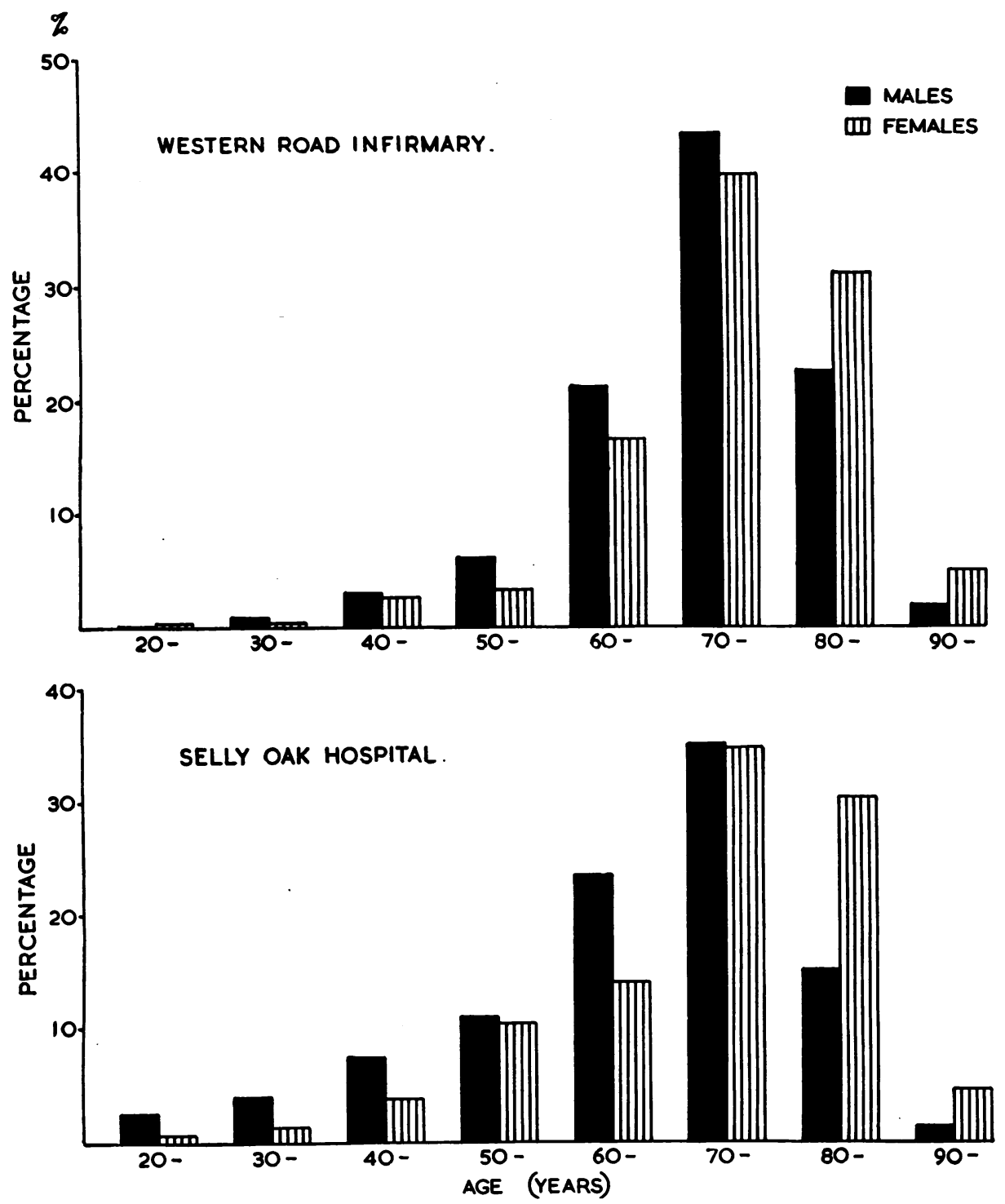

Fig. 1.-Age and sex distribution of patients in Birmingham hospitals for the chronic sick.

a rate of 1.4 per thousand of the total population of 1,104,200 (Registrar-General, 1948). Age distributions of patients in these two hospitals are given in Tables I and II (see also Fig. 1); in Western Road Infirmary and Selly Oak Hospital 92 per cent. and 81 per cent. respectively were over 60 . Affleck (1947) reported 87 per cent. over 60 in 788 cases in five Leeds hospitals, and in Surrey the County Medical Officer found that 71 per cent. of the chronic sick in hospitals were over 65 years 


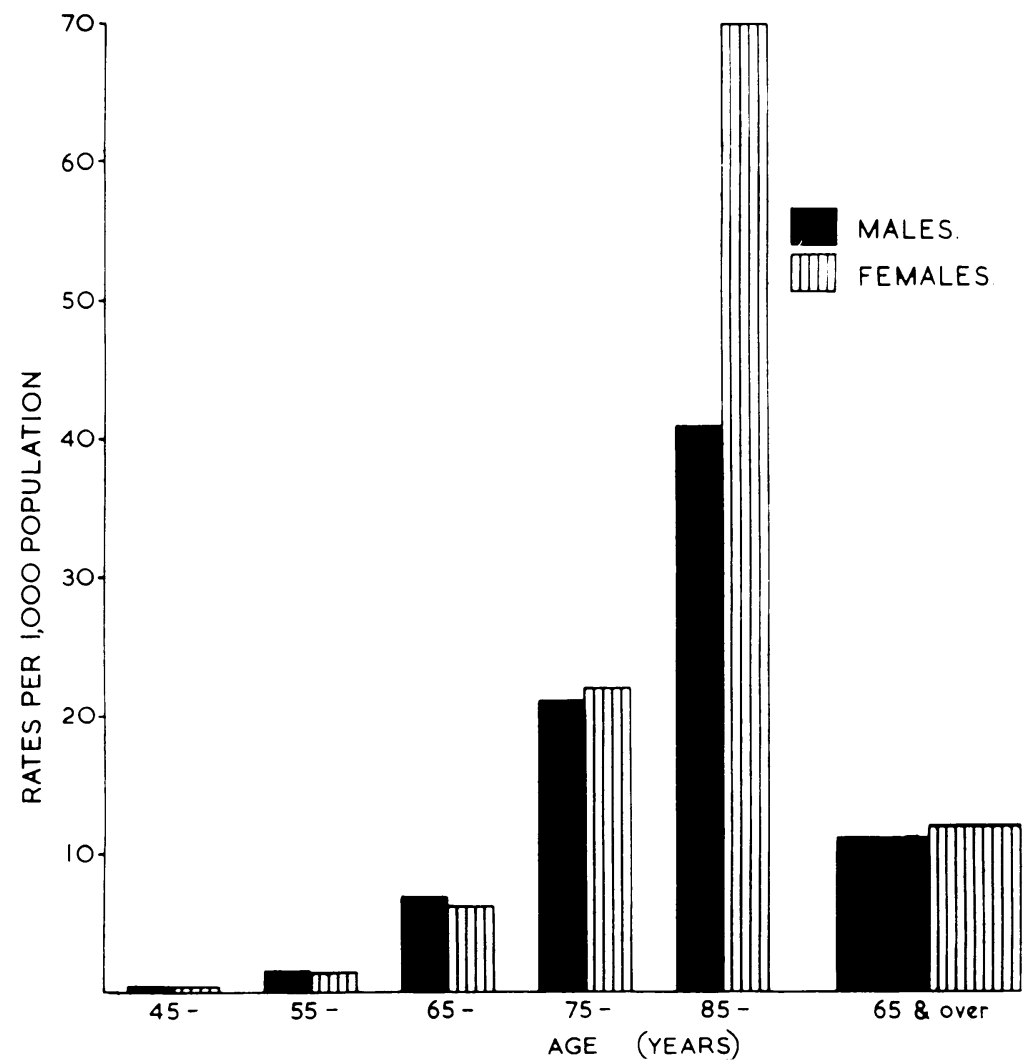

FIG. 2.-Age specific rates of patients in Birmingham hospitals for the chronic sick.

TABLE III

Patients in Hospitals for the Chronic Sick: Age Specific Rates per 1,000 or the Popliation (Birmingham, December 31, 1948)

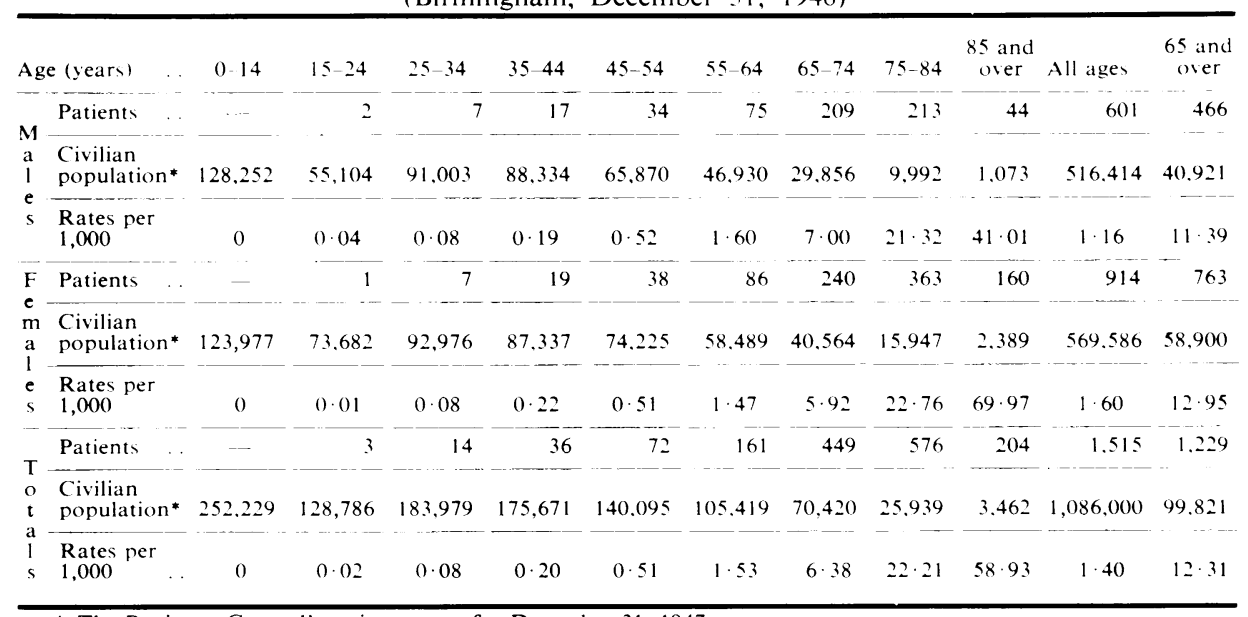

* The Registrar-General's estimates are for December 31. 1947. 
of age* (Ministry of Health, 1945). Data are not available for all hospitals in the country, but in spite of differences in age distribution in the few hospitals so far examined it is evident that a high proportion of the chronic sick are over 60.

It follows that bed requirements expressed as rates per thousand of the population at all ages are quite unsatisfactory for patients of whom the majority are in the higher age groups. We have therefore (Table III and Fig. 2) calculated age specific rates for the chronic sick in Birmingham hospitals, using figures for Western Road Infirmary and Selly Oak Hospital, and the Registrar-General's estimate of the sex and age distribution of the Birmingham population at December 31, 1947 (Registrar-General, 1949). The wide variation in different age groups underlines the unsatisfactory nature of rates expressed per thousand of the general population, and the figure of twelve beds per thousand persons aged 65 and over is a more useful estimate of the beds occupied by this type of patient. This figure cannot, of course, be used as an index of future requirements without reference to the possibility of re-allocation of responsibility between Regional Hospital Boards and Local Authorities.

TABLE IV

Duration of Stay in Hospital

\begin{tabular}{|c|c|c|c|c|c|c|}
\hline $\begin{array}{c}\text { Duration of stay } \\
\text { (months) }\end{array}$ & $0-5$ & $6-11$ & $12-23$ & $24-35$ & 36 and over & Totals \\
\hline Males & $\begin{array}{r}34 \cdot 5 \\
(157)\end{array}$ & $\begin{array}{l}13 \cdot 0 \\
(59)\end{array}$ & $\begin{array}{l}12 \cdot 3 \\
(56)\end{array}$ & $\begin{array}{c}9.9 \\
(45)\end{array}$ & $\begin{array}{l}30 \cdot 3 \\
(138)\end{array}$ & $\begin{array}{c}100 \\
(455)\end{array}$ \\
\hline Females .. & $\begin{array}{l}19 \cdot 1 \\
(105)\end{array}$ & $\begin{array}{l}12 \cdot 5 \\
(69)\end{array}$ & $\begin{array}{l}16 \cdot 4 \\
(90)\end{array}$ & $\begin{array}{l}15 \cdot 7 \\
(86)\end{array}$ & $\begin{array}{l}36 \cdot 3 \\
(200)\end{array}$ & $\begin{array}{l}100 \\
(550)\end{array}$ \\
\hline All patients & $\begin{array}{l}26 \cdot 1 \\
(262)\end{array}$ & $\begin{array}{l}12 \cdot 7 \\
(128)\end{array}$ & $\begin{array}{l}14 \cdot 4 \\
(146)\end{array}$ & $\begin{array}{l}13 \cdot 0 \\
(131)\end{array}$ & $\begin{array}{c}33 \cdot 8 \\
(338)\end{array}$ & $\begin{array}{c}100 \\
(1,005)\end{array}$ \\
\hline
\end{tabular}

\section{Duration of Stay in Hospital}

The mean duration of stay in hospital of all the patients in Western Road Infirmary is 33.2 months ( 1,010 days), about fifty times the average duration of stay of 15 to 20 days in general hospitals (Ministry of Health, 1945 and 1946). Table IV shows that 30 per cent. of the male and 36 per cent. of the female patients in Western Road have been in hospital for over three years; about one-third and one-fifth respectively have been in hospital for less than six months.

The prospect of admitting to general hospitals large numbers of patients who will spend months or years in hospital is unlikely to attract hospital authorities. But the situation is not as alarming as these figures suggest: first, because they are based on a population which includes many patients who should not be in hospital; and second, because the mean duration of stay obscures the considerable burden

* The patients in Surrey County Hospitals for the chronic sick included a number of younger patients suffering from tuberculosis. 
TABLE $\mathrm{V}$

Duration of Stay of all Patients admitted in 1946

\begin{tabular}{|c|c|c|c|c|c|c|}
\hline \multirow{3}{*}{ Sex } & \multirow{3}{*}{$\begin{array}{c}\text { No. } \\
\text { admitted }\end{array}$} & \multicolumn{4}{|c|}{ No. left hospital } & \multirow{3}{*}{$\begin{array}{c}\text { Remained } \\
\text { in hospital } \\
\text { for } 26 \\
\text { months } \\
\text { ( } 2 \text { years) } \\
\text { and over }\end{array}$} \\
\hline & & \multicolumn{2}{|c|}{ within $0-3$ months ${ }^{\dagger}$} & \multicolumn{2}{|c|}{ within $4-25$ months $\dagger$} & \\
\hline & & Died & Discharged & Died & Discharged & \\
\hline Males & $\begin{array}{c}100 \\
(1,470)\end{array}$ & $\begin{array}{l}29 \cdot 8 \\
(437)\end{array}$ & $\begin{array}{l}53 \cdot 3 \\
(784)\end{array}$ & $\begin{array}{c}7 \cdot 8 \\
(115)\end{array}$ & $\begin{array}{l}6 \cdot 3 \\
(93)\end{array}$ & $\begin{array}{l}2 \cdot 8 \\
(41)\end{array}$ \\
\hline Females & $\begin{array}{c}100 \\
(1.008)\end{array}$ & $\begin{array}{r}35 \cdot 2 \\
(355)\end{array}$ & $\begin{array}{l}38 \cdot 2 \\
(385)\end{array}$ & $\begin{array}{l}8 \cdot 1 \\
(82)\end{array}$ & $\begin{array}{l}10 \cdot 2 \\
(103)\end{array}$ & $\begin{array}{l}8 \cdot 3 \\
(83)\end{array}$ \\
\hline All patients & $\begin{array}{c}100 \\
(2,478)\end{array}$ & $\begin{array}{c}32 \cdot 0 \\
(792)\end{array}$ & $\begin{array}{c}47 \cdot 2 \\
(1,169)\end{array}$ & $\begin{array}{c}7 \cdot 9 \\
(197)\end{array}$ & $\begin{array}{c}7 \cdot 9 \\
(196)\end{array}$ & $\begin{array}{c}5 \cdot 0 \\
(124)\end{array}$ \\
\hline
\end{tabular}

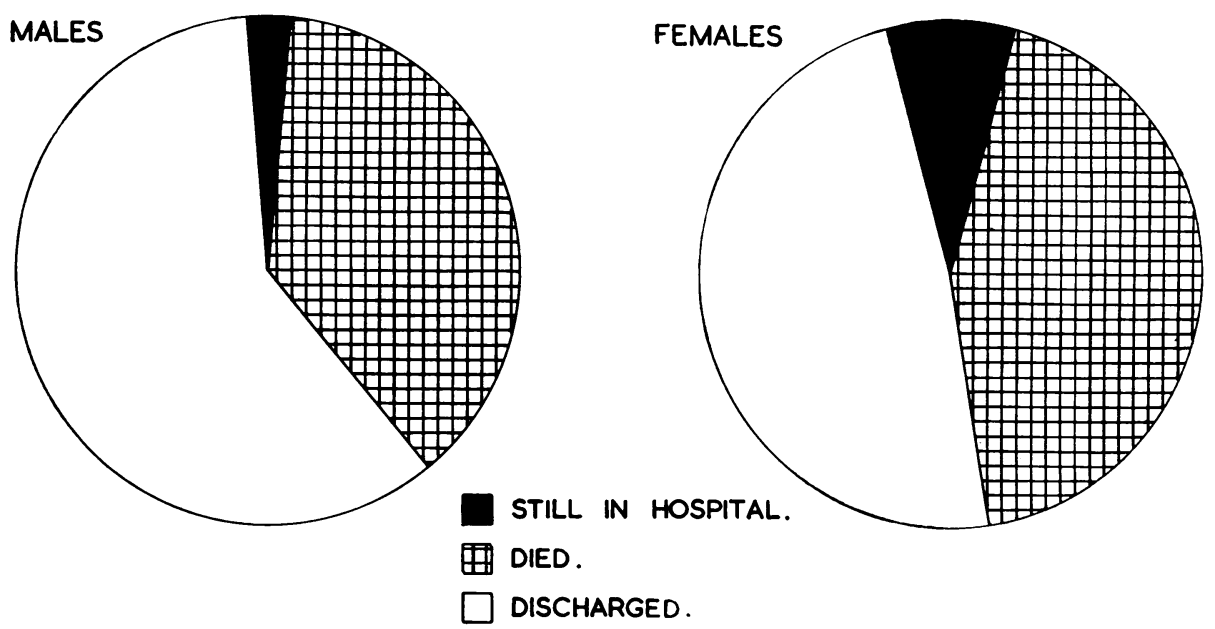

Fig. 3.-Fate of patients two years after admission to hospital (1946).

of acute work supported by the hospital. Table V (see also Fig. 3) gives the history of all patients admitted to Western Road Infirmary in the year 1946, ${ }^{*}$ and corrects the impression that the hospital admits chiefly patients who remain there for many years. Of all cases admitted in 1946, 79 per cent. died or were discharged within four months of their admission, and only 5 per cent. remained in hospital longer than two years. It is evident, therefore, that, although nearly half the beds are occupied by patients who have been in hospital over two years (Table IV, page 65), a considerable proportion of all patients admitted are in the acute or terminal stages of illness, and might be admitted to the wards of general hospitals without embarrassment to the character of the work there undertaken.

\footnotetext{
* We are indebted to Dr. Richard Padley, Statistician to the Regional Hospital Board, for supplying us with this material.

+ Months are lunar months of 28 days.
} 
TABLE VI

Number of previous Admissions to Hospitals for the Chronic Sick

\begin{tabular}{|c|c|c|c|c|c|c|c|c|c|c|}
\hline Sex & 0 & 1 & 2 & 3 & 4 & 5 & 6 & 7 & $\begin{array}{l}8 \text { and } \\
\text { over }\end{array}$ & Totals \\
\hline Males & $\begin{array}{l}62 \cdot 6 \\
(285)\end{array}$ & $\begin{array}{l}17 \cdot 8 \\
(81)\end{array}$ & $\begin{array}{l}7 \cdot 7 \\
(35)\end{array}$ & $\begin{array}{l}3 \cdot 5 \\
(16)\end{array}$ & $\begin{array}{l}2 \cdot 6 \\
(12)\end{array}$ & $\begin{array}{l}2 \cdot 0 \\
(9)\end{array}$ & $\begin{array}{l}0 \cdot 2 \\
(1)\end{array}$ & $\begin{array}{l}1 \cdot 6 \\
(7)\end{array}$ & $\begin{array}{l}2 \cdot 0 \\
(9)\end{array}$ & $\begin{array}{c}100 \\
(455)\end{array}$ \\
\hline Females & $\begin{array}{l}72 \cdot 5 \\
(399)\end{array}$ & $\begin{array}{l}19 \cdot 3 \\
(106)\end{array}$ & $\begin{array}{l}5 \cdot 1 \\
(28)\end{array}$ & $\begin{array}{l}1 \cdot 4 \\
(8)\end{array}$ & $\begin{array}{l}0.4 \\
(2)\end{array}$ & $\begin{array}{l}0 \cdot 2 \\
(1)\end{array}$ & $\begin{array}{l}0 \cdot 2 \\
(1)\end{array}$ & $\begin{array}{l}0 \cdot 2 \\
(1)\end{array}$ & $\begin{array}{l}0.7 \\
(4)\end{array}$ & $\begin{array}{c}100 \\
(550)\end{array}$ \\
\hline All patients & $\begin{array}{l}68 \cdot 1 \\
(684)\end{array}$ & $\begin{array}{l}18 \cdot 6 \\
(187)\end{array}$ & $\begin{array}{l}6 \cdot 2 \\
(63)\end{array}$ & $\begin{array}{l}2 \cdot 4 \\
(24)\end{array}$ & $\begin{array}{l}1 \cdot 4 \\
(14)\end{array}$ & $\begin{array}{l}1.0 \\
(10)\end{array}$ & $\begin{array}{l}0 \cdot 2 \\
(2)\end{array}$ & $\begin{array}{l}0.8 \\
(8)\end{array}$ & $\begin{array}{l}1 \cdot 3 \\
(13)\end{array}$ & $\begin{array}{c}100 \\
(1,005)\end{array}$ \\
\hline
\end{tabular}

Table VI records the numbers of times the patients in Western Road Infirmary had previously been admitted to this or to any other hospital for the chronic sick.

\section{Marital Status}

The observation that social as well as medical considerations determine the admission and retention of patients in hospitals for the chronic sick is supported by examination of the marital status of the patients at Western Road Infirmary. The marital status of the population of the City of Birmingham from which the patients are drawn is not known for a date later than that of the 1931 census (Registrar-General, 1938), but a comparison for persons aged 65 and over of the distribution at that time with recent figures given for Wolverhampton, by Sheldon (1948), suggests that there has been no gross change in the proportions in three classes: (a) single; $(b)$ married; $(c)$ widow(er)s or divorced. Table VII (see also

TABLE VII

Marital Status of Patients compared with the General Population (persons 65 years and OVER)

\begin{tabular}{|c|c|c|c|c|c|c|c|c|}
\hline \multirow[b]{2}{*}{ Source of data } & \multicolumn{4}{|c|}{ Males } & \multicolumn{4}{|c|}{ Females } \\
\hline & Single & Married & $\begin{array}{c}\text { Widowers } \\
\text { or } \\
\text { divorced }\end{array}$ & Total & Single & Married & \begin{tabular}{|c|} 
Widows \\
or \\
divorced
\end{tabular} & Total \\
\hline $\begin{array}{l}\text { Wolverhampton } \\
\text { (Sheldon, 1948) }\end{array}$ & $\begin{array}{l}7 \cdot 9 \\
(14)\end{array}$ & $\begin{array}{l}62 \cdot 2 \\
(110)\end{array}$ & $\begin{array}{l}29 \cdot 9 \\
(53)\end{array}$ & $\begin{array}{l}100 \\
(177)\end{array}$ & $\begin{array}{l}10 \cdot 8 \\
(31)\end{array}$ & $\begin{array}{l}34 \cdot 4 \\
(99)\end{array}$ & $\begin{array}{r}54 \cdot 8 \\
(158)\end{array}$ & $\begin{array}{c}100 \\
(288)\end{array}$ \\
\hline $\begin{array}{l}\text { Birmingham } \\
\text { (Census, 1931) }\end{array}$ & $\begin{array}{c}6.9 \\
(1,765)\end{array}$ & $\begin{array}{c}63 \cdot 3 \\
(16,065)\end{array}$ & $\begin{array}{c}29 \cdot 8 \\
(7,562)^{*}\end{array}$ & $\begin{array}{c}100 \\
(25,392)\end{array}$ & $\begin{array}{c}12 \cdot 3 \\
(4,323)\end{array}$ & $\begin{array}{c}33 \cdot 5 \\
(11,796)\end{array}$ & $\begin{array}{c}54 \cdot 2 \\
(19,069)^{*}\end{array}$ & $\begin{array}{c}100 \\
(35.188)\end{array}$ \\
\hline $\begin{array}{l}\text { Western Road } \\
\text { Infirmary, } 1948\end{array}$ & $\begin{array}{l}19 \cdot 0 \\
(71)\end{array}$ & $\begin{array}{l}24 \cdot 1 \\
(90)\end{array}$ & $\begin{array}{c}56 \cdot 9 \\
(212)^{\dagger}\end{array}$ & $\begin{array}{c}100 \\
(373)\end{array}$ & $\begin{array}{l}16 \cdot 6 \\
(80)\end{array}$ & $\begin{array}{r}9 \cdot 9 \\
(48)\end{array}$ & $\begin{array}{c}73 \cdot 5 \\
(355) \dagger\end{array}$ & $\begin{array}{c}100 \\
(483)\end{array}$ \\
\hline
\end{tabular}

* 23 males and 18 females divorced.

$\dagger 1$ male and no females divorced. 

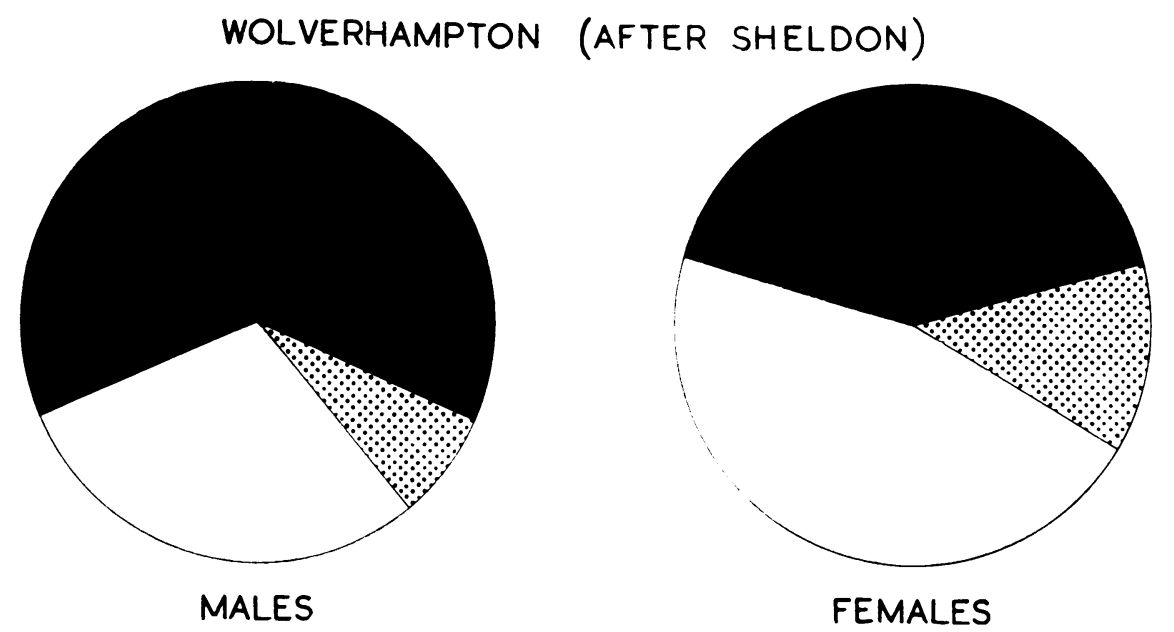

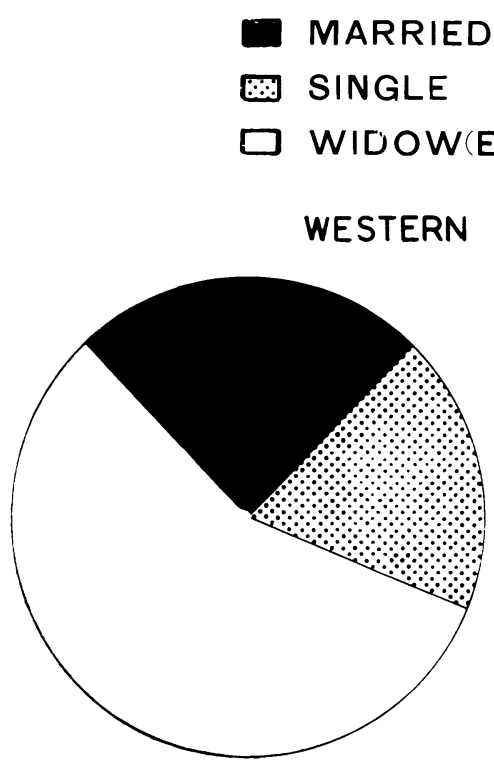

MALES

Fig. 4) shows that the infirmary population has very much higher proportions of individuals over 65 in classes $(a)$ and $(c)$, and correspondingly lower proportions in class (b). Table VIII (opposite) records the same data by age groups for the City of Birmingham (1931 Census) and for the hospital population. It is evident that the marital status of patients has a considerable bearing on the probability of their admission or retention in hospitals for the chronic sick. 
TABLE VIII

Marital Status related to Age and SeX

(The Survey compared with the general population of Birmingham at the 1931 census)

\begin{tabular}{|c|c|c|c|c|c|c|c|c|c|}
\hline \multirow{2}{*}{\multicolumn{2}{|c|}{ Age (years) }} & \multirow[b]{2}{*}{ Single } & \multicolumn{3}{|c|}{ Males (percentages) } & \multicolumn{4}{|c|}{ Females (percentages) } \\
\hline & & & Married & $\begin{array}{c}\text { Widowers } \\
\text { or } \\
\text { divorced }\end{array}$ & Total & Single & Married & $\begin{array}{l}\text { Widows } \\
\text { or } \\
\text { divorced }\end{array}$ & Total \\
\hline \multirow{2}{*}{$50-59$} & Survey & $28 \cdot 6$ & $57 \cdot 1$ & $14 \cdot 3$ & $\begin{array}{l}100 \\
(28)^{*}\end{array}$ & $33 \cdot 3$ & $44 \cdot 5$ & $22 \cdot 2$ & $\begin{array}{r}100 \\
(18)\end{array}$ \\
\hline & Census & $8 \cdot 4$ & $84 \cdot 7$ & $6 \cdot 9$ & $\begin{array}{c}100 \\
(51,090)\end{array}$ & $13 \cdot 1$ & $69 \cdot 4$ & $17 \cdot 5$ & $\begin{array}{c}100 \\
(57,139)\end{array}$ \\
\hline \multirow{2}{*}{$60-69$} & Survey & $29 \cdot 9$ & $44 \cdot 3$ & $25 \cdot 8$ & $\begin{array}{l}100 \\
(97)\end{array}$ & $30 \cdot 4$ & $23 \cdot 9$ & $45 \cdot 7$ & $\begin{array}{l}100 \\
(92)\end{array}$ \\
\hline & Census & $7 \cdot 9$ & $76 \cdot 0$ & $16 \cdot 1$ & $\begin{array}{c}100 \\
(30,249)\end{array}$ & $12 \cdot 4$ & $53 \cdot 0$ & $34 \cdot 6$ & $\begin{array}{c}100 \\
(34,992)\end{array}$ \\
\hline \multirow{2}{*}{$70-79$} & Survey & $20 \cdot 2$ & $26 \cdot 3$ & $53 \cdot 5$ & $\begin{array}{c}100 \\
(198)\end{array}$ & $17 \cdot 4$ & $10 \cdot 5$ & $72 \cdot 1$ & $\begin{array}{c}100 \\
(219)\end{array}$ \\
\hline & Census & $6 \cdot 5$ & $58 \cdot 1$ & $35 \cdot 4$ & $\begin{array}{c}100 \\
(11,204)\end{array}$ & $12 \cdot 1$ & $28 \cdot 0$ & $59 \cdot 9$ & $\begin{array}{c}100 \\
(16,329)\end{array}$ \\
\hline \multirow{2}{*}{80 and over } & Survey & $8 \cdot 9$ & $12 \cdot 3$ & $78 \cdot 8$ & $\begin{array}{c}100 \\
(113)\end{array}$ & $12 \cdot 4$ & $4 \cdot 4$ & $83 \cdot 2$ & $\begin{array}{c}100 \\
(202)\end{array}$ \\
\hline & Census & $4 \cdot 9$ & $34 \cdot 8$ & $60 \cdot 3$ & $\begin{array}{c}100 \\
(1,923)\end{array}$ & $11 \cdot 0$ & $11 \cdot 0$ & $78 \cdot 0$ & $\begin{array}{c}100 \\
(4,005)\end{array}$ \\
\hline
\end{tabular}

* Numbers in each age group are given in brackets.

TABLE IX

Residence of Old People in Wolverhampton, 1948, and of Patients in Birmingham PRior to ADMISSION TO WESTERN ROAD INFIRMARY

\begin{tabular}{|c|c|c|c|c|c|c|}
\hline Place of Residence & Own home & $\begin{array}{c}\text { Relatives' } \\
\text { home }\end{array}$ & Lodgings & $\begin{array}{l}\text { Municipal } \\
\text { homes, } \\
\text { hostels, and } \\
\text { common } \\
\text { lodging } \\
\text { houses }\end{array}$ & Unknown & Totals \\
\hline $\begin{array}{l}\text { Residence of old people in } \\
\text { Wolverhampton, 1948 } \\
\text { (after Sheldon) }\end{array}$ & $\begin{array}{l}71 \cdot 1 \\
(339)\end{array}$ & $\begin{array}{l}18 \cdot 2 \\
(87)\end{array}$ & $\begin{array}{l}7 \cdot 8 \\
(37)\end{array}$ & $\begin{array}{l}1 \cdot 9 \\
(9)\end{array}$ & $\begin{array}{l}1 \cdot 0 \\
(5)\end{array}$ & $\frac{100}{(477) \dagger}$ \\
\hline $\begin{array}{l}\text { Residence of patients in } \\
\text { Western Road Infirmary } \\
\text { prior to admission }\end{array}$ & $\begin{array}{l}43 \cdot 4 \\
(436)\end{array}$ & $\begin{array}{l}22 \cdot 5 \\
(226)\end{array}$ & $\begin{array}{l}14 \cdot 8 \\
(149)\end{array}$ & $\begin{array}{l}16 \cdot 9 \\
(170)\end{array}$ & $\begin{array}{l}2 \cdot 4 \\
(24)\end{array}$ & $\begin{array}{c}100 \\
(1,005)\end{array}$ \\
\hline
\end{tabular}

$\dagger 143$ men and 334 women. 
TABLE $\mathrm{X}$

Domestic Resources available to Patients in relation to Duration of Stay

\begin{tabular}{|c|c|c|c|c|c|c|c|c|c|c|c|c|}
\hline \multirow[b]{3}{*}{$\begin{array}{l}\text { Duration } \\
\text { of stay } \\
\text { (months) }\end{array}$} & \multicolumn{6}{|c|}{ Males } & \multicolumn{6}{|c|}{ Females } \\
\hline & \multicolumn{3}{|c|}{ Home available } & \multirow[b]{2}{*}{$\begin{array}{l}\text { No } \\
\text { home } \\
\text { avail- } \\
\text { able }\end{array}$} & \multirow[b]{2}{*}{$\underset{\text { known }}{\text { Un- }}$} & \multirow[b]{2}{*}{ Totals } & \multicolumn{3}{|c|}{ Home available } & \multirow[b]{2}{*}{$\begin{array}{l}\text { No } \\
\text { home } \\
\text { avail- } \\
\text { able }\end{array}$} & \multirow[b]{2}{*}{$\underset{\text { known }}{\text { Un- }}$} & \multirow[b]{2}{*}{ Totals } \\
\hline & $\begin{array}{l}\text { With } \\
\text { dom- } \\
\text { estic } \\
\text { service } \\
\text { and } \\
\text { simple } \\
\text { nurs- } \\
\text { ing }\end{array}$ & $\begin{array}{l}\text { With } \\
\text { dom- } \\
\text { estic } \\
\text { service } \\
\text { but } \\
\text { with- } \\
\text { out } \\
\text { simple } \\
\text { nurs- } \\
\text { ing }\end{array}$ & $\begin{array}{l}\text { With- } \\
\text { out } \\
\text { dom- } \\
\text { estic } \\
\text { service } \\
\text { or } \\
\text { simple } \\
\text { nurs- } \\
\text { ing }\end{array}$ & & & & $\begin{array}{l}\text { With } \\
\text { dom- } \\
\text { estic } \\
\text { service } \\
\text { and } \\
\text { simple } \\
\text { nurs- } \\
\text { ing }\end{array}$ & $\begin{array}{l}\text { With } \\
\text { dom- } \\
\text { estic } \\
\text { service } \\
\text { but } \\
\text { with- } \\
\text { out } \\
\text { simple } \\
\text { nurs- } \\
\text { ing }\end{array}$ & $\begin{array}{l}\text { With- } \\
\text { out } \\
\text { dom- } \\
\text { estic } \\
\text { service } \\
\text { or } \\
\text { simple } \\
\text { nurs- } \\
\text { ing }\end{array}$ & & & \\
\hline $0-2$ & $\begin{array}{l}9 \cdot 6 \\
(11)\end{array}$ & $\begin{array}{l}31 \cdot 6 \\
(36)\end{array}$ & $\begin{array}{l}27 \cdot 2 \\
(31)\end{array}$ & $\begin{array}{l}30 \cdot 7 \\
(35)\end{array}$ & $\begin{array}{l}0.9 \\
(1)\end{array}$ & $\begin{array}{c}100 \\
(114)\end{array}$ & $\begin{array}{l}3 \cdot 0 \\
(2)\end{array}$ & $\begin{array}{l}20 \cdot 9 \\
(14)\end{array}$ & $\begin{array}{l}38 \cdot 8 \\
(26)\end{array}$ & $\begin{array}{l}34 \cdot 3 \\
(23)\end{array}$ & $\begin{array}{l}3 \cdot 0 \\
(2)\end{array}$ & $\begin{array}{r}100 \\
(67)\end{array}$ \\
\hline $3-11$ & $\begin{array}{l}1 \cdot 0 \\
(1)\end{array}$ & $\begin{array}{l}24 \cdot 5 \\
(25)\end{array}$ & $\begin{array}{l}18 \cdot 6 \\
(19)\end{array}$ & $\begin{array}{l}55 \cdot 9 \\
(57)\end{array}$ & - & $\begin{array}{c}100 \\
(102)\end{array}$ & $\begin{array}{l}2 \cdot 8 \\
(3)\end{array}$ & $\begin{array}{l}19 \cdot 6 \\
(21)\end{array}$ & $\begin{array}{l}28 \cdot 1 \\
(30)\end{array}$ & $\begin{array}{l}48 \cdot 6 \\
(52)\end{array}$ & $\begin{array}{l}0 \cdot 9 \\
(1)\end{array}$ & $\begin{array}{c}100 \\
(107)\end{array}$ \\
\hline $12-35$ & - & $\begin{array}{l}17 \cdot 8 \\
(18)\end{array}$ & $\begin{array}{l}14 \cdot 8 \\
(15)\end{array}$ & $\begin{array}{c}64 \cdot 4 \\
(65)\end{array}$ & $\begin{array}{l}3 \cdot 0 \\
(3)\end{array}$ & $\begin{array}{c}100 \\
(101)\end{array}$ & $\begin{array}{l}0 \cdot 6 \\
(1)\end{array}$ & $\begin{array}{c}20 \cdot 4 \\
(36)\end{array}$ & $\begin{array}{l}29 \cdot 0 \\
(51)\end{array}$ & $\begin{array}{l}48 \cdot 3 \\
(85)\end{array}$ & $\begin{array}{l}1 \cdot 7 \\
(3)\end{array}$ & $\begin{array}{l}100 \\
(176)\end{array}$ \\
\hline 36 and over & 一 & $\begin{array}{c}9 \cdot 4 \\
(13)\end{array}$ & $\begin{array}{l}15 \cdot 9 \\
(22)\end{array}$ & $\begin{array}{l}72 \cdot 5 \\
(100)\end{array}$ & $\begin{array}{l}2 \cdot 2 \\
(3)\end{array}$ & $\begin{array}{c}100 \\
(138)\end{array}$ & - & $\begin{array}{l}7 \cdot 5 \\
(15)\end{array}$ & $\begin{array}{l}17 \cdot 5 \\
(35)\end{array}$ & $\begin{array}{c}68 \cdot 5 \\
(137)\end{array}$ & $\begin{array}{r}6 \cdot 5 \\
(13)\end{array}$ & $\begin{array}{c}100 \\
(200)\end{array}$ \\
\hline Totals & $\begin{array}{l}2 \cdot 6 \\
(12)\end{array}$ & $\begin{array}{l}20 \cdot 2 \\
(92)\end{array}$ & $\begin{array}{l}19 \cdot 1 \\
(87)\end{array}$ & $\begin{array}{l}56 \cdot 5 \\
(257)\end{array}$ & $\begin{array}{l}1 \cdot 6 \\
(7)\end{array}$ & $\begin{array}{c}100 \\
(455)\end{array}$ & $\begin{array}{l}1 \cdot 1 \\
(6)\end{array}$ & $\begin{array}{l}15 \cdot 6 \\
(86)\end{array}$ & $\begin{array}{l}25 \cdot 8 \\
(142)\end{array}$ & $\begin{array}{l}54 \cdot 0 \\
(297)\end{array}$ & $\begin{array}{c}3 \cdot 5 \\
(19)\end{array}$ & $\begin{array}{c}100 \\
(550)\end{array}$ \\
\hline
\end{tabular}

\section{DOMESTIC Resources}

The extent to which Local Authorities can meet their responsibilities by service to the chronic sick in their homes can only be determined after consideration of the medical condition and domestic resources of patients awaiting admission to hospital. Until information of this kind is available we may usefully draw attention to observations on the hospital population which have a bearing on the possibility of home service. Most patients were admitted from home. Table IX shows that two-thirds of the patients in Western Road Infirmary were living at their own homes or with relatives, and that one-third were in lodgings, municipal homes, hostels, and common lodging houses. The data are compared with those of Sheldon (1948) for old people (not in hospitals) in Wolverhampton, of whom 90 per cent. were living at home. Here again we must keep in view the difference between the resident hospital population and the admissions, since, as might be expected, Table X shows that for both sexes the proportion of patients without a home to which they could return increases with the duration of stay in hospital. For this, two explanations are possible: (1) patients not admitted from home may remain in hospital because they have no home to which they could return; (2) patients admitted from home may lose their homes if they are retained in hospital for long periods for medical reasons. Table XI suggests that both explanations are relevant. 
TABLE XI

Home available at the time of the Survey to Patients admitted to Hospital from Different SOURCES

\begin{tabular}{|c|c|c|c|c|c|c|c|c|}
\hline \multirow{3}{*}{$\begin{array}{l}\text { Places from which } \\
\text { patients were } \\
\text { admitted to hospital }\end{array}$} & \multicolumn{8}{|c|}{ Availability of home at the time of the survey } \\
\hline & \multicolumn{4}{|c|}{ Males } & \multicolumn{4}{|c|}{ Females } \\
\hline & $\begin{array}{c}\text { Home } \\
\text { available }\end{array}$ & $\begin{array}{l}\text { No home } \\
\text { available }\end{array}$ & $\underset{\text { known- }}{\text { Un }}$ & Totals & $\begin{array}{c}\text { Home } \\
\text { available }\end{array}$ & $\begin{array}{l}\text { No home } \\
\text { available }\end{array}$ & $\underset{\text { known }}{\text { Un- }}$ & Totals \\
\hline Own home .. & $\begin{array}{l}75 \cdot 1 \\
(133)\end{array}$ & $\begin{array}{l}24 \cdot 3 \\
(43)\end{array}$ & $\begin{array}{l}0.6 \\
(1)\end{array}$ & $\begin{array}{l}100 \\
(177)\end{array}$ & $\begin{array}{l}51 \cdot 0 \\
(132)\end{array}$ & $\begin{array}{l}47 \cdot 1 \\
(122)\end{array}$ & $\begin{array}{l}1.9 \\
(5)\end{array}$ & $\begin{array}{l}100 \\
(259)\end{array}$ \\
\hline Relatives' home & $\begin{array}{l}60 \cdot 2 \\
(50)\end{array}$ & $\begin{array}{l}38 \cdot 6 \\
(32)\end{array}$ & $\begin{array}{l}1 \cdot 2 \\
(1)\end{array}$ & $\begin{array}{l}100 \\
(83)\end{array}$ & $\begin{array}{l}62 \cdot 3 \\
(89)\end{array}$ & $\begin{array}{l}37 \cdot 7 \\
(54)\end{array}$ & - & $\begin{array}{l}100 \\
(143)\end{array}$ \\
\hline Lodgings & $\begin{array}{c}10 \cdot 8 \\
(8)\end{array}$ & $\begin{array}{l}89 \cdot 2 \\
(66)\end{array}$ & - & $\begin{array}{l}100 \\
(74)\end{array}$ & $\begin{array}{l}16 \cdot 0 \\
(12)\end{array}$ & $\begin{array}{l}84 \cdot 0 \\
(63)\end{array}$ & - & $\begin{array}{l}100 \\
(75)\end{array}$ \\
\hline Municipal home & - & $\begin{array}{l}100 \\
(75)\end{array}$ & - & $\begin{array}{l}100 \\
(75)\end{array}$ & - & $\begin{array}{l}100 \\
(37)\end{array}$ & - & $\begin{array}{l}100 \\
(37)\end{array}$ \\
\hline Other & - & $\begin{array}{l}100 \\
(40)\end{array}$ & - & $\begin{array}{l}100 \\
(40)\end{array}$ & $\begin{array}{l}5 \cdot 5 \\
(1)\end{array}$ & $\begin{array}{l}89 \cdot 0 \\
(16)\end{array}$ & $\begin{array}{l}5 \cdot 5 \\
(1)\end{array}$ & $\begin{array}{l}100 \\
(18)\end{array}$ \\
\hline Unknown .. & - & $\begin{array}{l}16 \cdot 7 \\
(1)\end{array}$ & $\begin{array}{c}83 \cdot 3 \\
(5)\end{array}$ & $\begin{array}{l}100 \\
(6)\end{array}$ & - & $\begin{array}{l}27 \cdot 8 \\
(5)\end{array}$ & $\begin{array}{l}72 \cdot 2 \\
(13)\end{array}$ & $\begin{array}{l}100 \\
(18)\end{array}$ \\
\hline Totals & $\begin{array}{l}41 \cdot 9 \\
(191)\end{array}$ & $\begin{array}{l}56 \cdot 5 \\
(257)\end{array}$ & $\begin{array}{l}1.6 \\
(7)\end{array}$ & $\begin{array}{c}100 \\
(455)\end{array}$ & $\begin{array}{l}42 \cdot 5 \\
(234)\end{array}$ & $\begin{array}{l}54 \cdot 0 \\
(297)\end{array}$ & $\begin{array}{l}3 \cdot 5 \\
(19)\end{array}$ & $\begin{array}{c}100 \\
(550)\end{array}$ \\
\hline
\end{tabular}

TABLE XII

Attitude to leaving Hospital related to Duration of Stay

\begin{tabular}{|c|c|c|c|c|c|c|c|c|}
\hline \multirow{2}{*}{$\begin{array}{l}\text { Duration of stay } \\
\text { (months) }\end{array}$} & \multicolumn{4}{|c|}{ Males } & \multicolumn{4}{|c|}{ Females } \\
\hline & Willing & $\begin{array}{c}\text { Reluc- } \\
\text { tant }\end{array}$ & $\underset{\substack{\text { Un- } \\
\text { known }}}{\text { Un }}$ & Totals & Willing & $\begin{array}{l}\text { Reluc- } \\
\text { tant }\end{array}$ & $\begin{array}{c}\text { Un- } \\
\text { known }\end{array}$ & Totals \\
\hline $0-2$ & $\begin{array}{l}65 \cdot 8 \\
(75)\end{array}$ & $\begin{array}{l}24 \cdot 6 \\
(28)\end{array}$ & $\begin{array}{l}9 \cdot 6 \\
(11)\end{array}$ & $\begin{array}{l}100 \\
(114)\end{array}$ & $\begin{array}{l}67 \cdot 2 \\
(45)\end{array}$ & $\begin{array}{l}19 \cdot 4 \\
(13)\end{array}$ & $\begin{array}{l}13 \cdot 4 \\
(9)\end{array}$ & $\begin{array}{r}100 \\
(67)\end{array}$ \\
\hline $3-11$ & $\begin{array}{l}60 \cdot 8 \\
(62)\end{array}$ & $\begin{array}{l}29 \cdot 4 \\
(30)\end{array}$ & $\begin{array}{l}9 \cdot 8 \\
(10)\end{array}$ & $\begin{array}{c}100 \\
(102)\end{array}$ & $\begin{array}{l}53 \cdot 3 \\
(57)\end{array}$ & $\begin{array}{l}26 \cdot 2 \\
(28)\end{array}$ & $\begin{array}{l}20 \cdot 5 \\
(22)\end{array}$ & $\begin{array}{l}100 \\
(107)\end{array}$ \\
\hline $12-35$ & $\begin{array}{l}48 \cdot 5 \\
(49)\end{array}$ & $\begin{array}{l}32 \cdot 7 \\
(33)\end{array}$ & $\begin{array}{l}18 \cdot 8 \\
(19)\end{array}$ & $\begin{array}{l}100 \\
(101)\end{array}$ & $\begin{array}{l}44 \cdot 9 \\
(79)\end{array}$ & $\begin{array}{l}34 \cdot 1 \\
(60)\end{array}$ & $\begin{array}{l}21 \cdot 0 \\
(37)\end{array}$ & $\begin{array}{l}100 \\
(176)\end{array}$ \\
\hline 36 and over & $\begin{array}{l}45 \cdot 7 \\
(63)\end{array}$ & $\begin{array}{l}39 \cdot 1 \\
(54)\end{array}$ & $\begin{array}{l}15 \cdot 2 \\
(21)\end{array}$ & $\begin{array}{c}100 \\
(138)\end{array}$ & $\begin{array}{l}28 \cdot 5 \\
(57)\end{array}$ & $\begin{array}{l}44 \cdot 5 \\
(89)\end{array}$ & $\begin{array}{l}27 \cdot 0 \\
(54)\end{array}$ & $\begin{array}{c}100 \\
(200)\end{array}$ \\
\hline Totals & $\begin{array}{l}54 \cdot 7 \\
(249)\end{array}$ & $\begin{array}{l}31.9 \\
(145)\end{array}$ & $\begin{array}{l}13 \cdot 4 \\
(61)\end{array}$ & $\begin{array}{c}100 \\
(455)\end{array}$ & $\begin{array}{l}43 \cdot 3 \\
(238)\end{array}$ & $\begin{array}{l}34 \cdot 5 \\
(190)\end{array}$ & $\begin{array}{l}22 \cdot 2 \\
(122)\end{array}$ & $\begin{array}{c}100 \\
(550)\end{array}$ \\
\hline
\end{tabular}

About a quarter of the men and half of the women who had a home of their own when admitted had no home at the time of the survey. We may conclude that considerably more than two-thirds of the chronic sick in Western Road Infirmary have been admitted to hospital from their own homes or from those of relatives. 
TABLE XIII

Patients' Occupation in Hospital

\begin{tabular}{|c|c|c|c|c|c|c|c|c|c|}
\hline \multirow[b]{2}{*}{ Sex } & \multirow[b]{2}{*}{ Occupied } & \multicolumn{7}{|c|}{ Reasons for not being occupied } & \multirow[b]{2}{*}{ Totals } \\
\hline & & $\begin{array}{l}\text { Acute } \\
\text { illness }\end{array}$ & $\begin{array}{l}\text { Gross } \\
\text { mental } \\
\text { change }\end{array}$ & $\begin{array}{l}\text { Blind- } \\
\text { ness }\end{array}$ & $\begin{array}{l}\text { Poor } \\
\text { vision }\end{array}$ & Illiteracy & $\begin{array}{l}\text { Other } \\
\text { reasons* }\end{array}$ & $\begin{array}{l}\text { No } \\
\text { apparent } \\
\text { reason }\end{array}$ & \\
\hline Males & $\begin{array}{l}61 \cdot 3 \\
(279)\end{array}$ & $\begin{array}{l}4 \cdot 4 \\
(20)\end{array}$ & $\begin{array}{l}13 \cdot 0 \\
(59)\end{array}$ & $\begin{array}{c}3 \cdot 5 \\
(16)\end{array}$ & $\begin{array}{c}7 \cdot 7 \\
(35)\end{array}$ & $\begin{array}{c}3 \cdot 1 \\
(14)\end{array}$ & $\begin{array}{l}1 \cdot 3 \\
(6)\end{array}$ & $\begin{array}{l}5 \cdot 7 \\
(26)\end{array}$ & $\begin{array}{c}100 \\
(455)\end{array}$ \\
\hline Females & $\begin{array}{l}47 \cdot 2 \\
(260)\end{array}$ & $\begin{array}{l}3 \cdot 1 \\
(17)\end{array}$ & $\begin{array}{l}16 \cdot 2 \\
(89)\end{array}$ & $\begin{array}{l}4 \cdot 2 \\
(23)\end{array}$ & $\begin{array}{l}7 \cdot 1 \\
(39)\end{array}$ & $\begin{array}{l}3 \cdot 8 \\
(21)\end{array}$ & $\begin{array}{l}5 \cdot 3 \\
(29)\end{array}$ & $\begin{array}{l}13 \cdot 1 \\
(72)\end{array}$ & $\begin{array}{c}100 \\
(550)\end{array}$ \\
\hline All patients & $\begin{array}{l}53 \cdot 6 \\
(539)\end{array}$ & $\begin{array}{l}3 \cdot 7 \\
(37)\end{array}$ & $\begin{array}{l}14 \cdot 7 \\
(148)\end{array}$ & $\begin{array}{c}3 \cdot 9 \\
(39)\end{array}$ & $\begin{array}{c}7 \cdot 4 \\
(74)\end{array}$ & $\begin{array}{l}3 \cdot 5 \\
(35)\end{array}$ & $\begin{array}{l}3 \cdot 5 \\
(35)\end{array}$ & $\begin{array}{l}9 \cdot 7 \\
(98)\end{array}$ & $\begin{array}{c}100 \\
(1,005)\end{array}$ \\
\hline
\end{tabular}

* Hemiplegia with severe residual paralysis, advanced nervous disease, gross arthritis.

TABLE XIV

Frequency of Visits Related to Duration of Stay

\begin{tabular}{|c|c|c|c|c|c|c|c|c|c|c|c|c|}
\hline \multirow[b]{2}{*}{$\begin{array}{l}\text { Dura- } \\
\text { tion of } \\
\text { stay } \\
\text { (m'nths) }\end{array}$} & \multicolumn{5}{|c|}{ Males } & & & \multicolumn{5}{|c|}{ Females } \\
\hline & $\begin{array}{l}\text { Twice } \\
\text { weekly }\end{array}$ & Weekly & $\begin{array}{l}\text { Two- } \\
\text { or } \\
\text { three- } \\
\text { weekly }\end{array}$ & $\begin{array}{l}\text { Monthly } \\
\text { or less }\end{array}$ & None & Totals & $\begin{array}{l}\text { Twice } \\
\text { weekly }\end{array}$ & Weekly & $\begin{array}{l}\text { Two- } \\
\text { or } \\
\text { three- } \\
\text { weekly }\end{array}$ & $\begin{array}{l}\text { Monthly } \\
\text { or less }\end{array}$ & None & Totals \\
\hline $0-2$ & $\begin{array}{l}50 \cdot 0 \\
(57)\end{array}$ & $\begin{array}{l}29 \cdot 8 \\
(34)\end{array}$ & $\begin{array}{l}5 \cdot 3 \\
(6)\end{array}$ & $\begin{array}{l}3 \cdot 5 \\
(4)\end{array}$ & $\begin{array}{l}11 \cdot 4 \\
(13)\end{array}$ & $\begin{array}{c}100 \\
(114)\end{array}$ & $\begin{array}{l}44 \cdot 8 \\
(30)\end{array}$ & $\begin{array}{l}38 \cdot 8 \\
(26)\end{array}$ & $\begin{array}{l}4 \cdot 5 \\
(3)\end{array}$ & $\begin{array}{l}7 \cdot 4 \\
(5)\end{array}$ & $\begin{array}{l}4 \cdot 5 \\
(3)\end{array}$ & $\begin{array}{l}100 \\
(67)\end{array}$ \\
\hline $3-11$ & $\begin{array}{l}31 \cdot 4 \\
(32)\end{array}$ & $\begin{array}{l}36 \cdot 3 \\
(37)\end{array}$ & $\begin{array}{c}9 \cdot 8 \\
(10)\end{array}$ & $\begin{array}{l}12 \cdot 7 \\
(13)\end{array}$ & $\begin{array}{l}9 \cdot 8 \\
(10)\end{array}$ & $\begin{array}{c}100 \\
(102)\end{array}$ & $\begin{array}{l}43 \cdot 9 \\
(47)\end{array}$ & $\begin{array}{l}35 \cdot 5 \\
(38)\end{array}$ & $\begin{array}{l}12 \cdot 2 \\
(13)\end{array}$ & $\begin{array}{l}5 \cdot 6 \\
(6)\end{array}$ & $\begin{array}{l}2 \cdot 8 \\
(3)\end{array}$ & $\begin{array}{c}100 \\
(107)\end{array}$ \\
\hline $12-35$ & $\begin{array}{l}14 \cdot 9 \\
(15)\end{array}$ & $\begin{array}{l}27 \cdot 7 \\
(28)\end{array}$ & $\begin{array}{l}16 \cdot 8 \\
(17)\end{array}$ & $\begin{array}{l}18 \cdot 8 \\
(19)\end{array}$ & $\begin{array}{l}21 \cdot 8 \\
(22)\end{array}$ & $\begin{array}{c}100 \\
(101)\end{array}$ & $\begin{array}{c}32 \cdot 9 \\
(58)\end{array}$ & $\begin{array}{l}45 \cdot 5 \\
(80)\end{array}$ & $\begin{array}{l}10 \cdot 2 \\
(18)\end{array}$ & $\begin{array}{l}9 \cdot 1 \\
(16)\end{array}$ & $\begin{array}{l}2 \cdot 3 \\
(4)\end{array}$ & $\begin{array}{c}100 \\
(176)\end{array}$ \\
\hline $\begin{array}{l}36 \text { and } \\
\text { over }\end{array}$ & $\begin{array}{l}3 \cdot 6 \\
(5)\end{array}$ & $\begin{array}{l}31 \cdot 2 \\
(43) .\end{array}$ & $\begin{array}{l}21 \cdot 8 \\
(30)\end{array}$ & $\begin{array}{l}24 \cdot 6 \\
(34)\end{array}$ & $\begin{array}{l}18 \cdot 8 \\
(26)\end{array}$ & $\begin{array}{c}100 \\
(138)\end{array}$ & $\begin{array}{l}16 \cdot 5 \\
(33)\end{array}$ & $\begin{array}{l}33 \cdot 0 \\
(66)\end{array}$ & $\begin{array}{l}19 \cdot 0 \\
(38)\end{array}$ & $\begin{array}{l}18 \cdot 0 \\
(36)\end{array}$ & $\begin{array}{l}13 \cdot 5 \\
(27)\end{array}$ & $\begin{array}{l}100 \\
(200)\end{array}$ \\
\hline Totals & $\begin{array}{l}24 \cdot 0 \\
(109)\end{array}$ & $\begin{array}{c}31 \cdot 2 \\
(142)\end{array}$ & $\begin{array}{c}13 \cdot 8 \\
(63)\end{array}$ & $\begin{array}{l}15 \cdot 4 \\
(70)\end{array}$ & $\begin{array}{l}15 \cdot 6 \\
(71)\end{array}$ & $\begin{array}{c}100 \\
(455)\end{array}$ & $\begin{array}{c}30 \cdot 5 \\
(168)\end{array}$ & $\begin{array}{c}38 \cdot 2 \\
(210)\end{array}$ & $\begin{array}{l}13 \cdot 1 \\
(72)\end{array}$ & $\begin{array}{l}11 \cdot 5 \\
(63)\end{array}$ & $\begin{array}{l}6 \cdot 7 \\
(37)\end{array}$ & $\begin{array}{c}100 \\
(550)\end{array}$ \\
\hline
\end{tabular}

\section{Miscellaneous Data}

(a) Attitude to leaving Hospital.-We inquired whether the patients investigated at Western Road Infirmary would be willing to leave hospital. It was soon evident that for patients who have no home, or whose medical condition prohibits the possibility of discharge, the question of willingness has little meaning. The results of the interrogation given in Table XII may be interpreted by the statement that only half the patients are known to be willing to leave hospital if circumstances permit.

(b) Occupation in Hospital.-About two-fifths of the men and over half of the women have no occupation (such as reading or sewing) in hospital (see Table XIII). In many cases there are reasons (acute illness, gross mental change, blindness, 
TABLE XV

SOURCE OF INCOME

\begin{tabular}{|c|c|c|c|c|c|c|c|}
\hline Sex and Age & $\begin{array}{l}\text { Old age } \\
\text { pension } \\
\text { (contri- } \\
\text { butory and } \\
\text { non-con- } \\
\text { tributory) }\end{array}$ & $\begin{array}{c}\text { National } \\
\text { assistance }\end{array}$ & $\begin{array}{l}\text { National } \\
\text { insurance }\end{array}$ & $\begin{array}{c}\text { Other } \\
\text { sources* }\end{array}$ & None & Unknown & Totals \\
\hline $\begin{array}{l}\text { Males } \\
\text { Under } 65 \text { years }\end{array}$ & - & $\begin{array}{l}41 \cdot 5 \\
(34)\end{array}$ & $\begin{array}{l}39 \cdot 0 \\
(32)\end{array}$ & $\begin{array}{c}11 \cdot 0 \\
(9)\end{array}$ & $\begin{array}{l}7 \cdot 3 \\
(6)\end{array}$ & $\begin{array}{l}1 \cdot 2 \\
(1)\end{array}$ & $\begin{array}{r}100 \\
(82)\end{array}$ \\
\hline $\begin{array}{l}65 \text { years and } \\
\text { over }\end{array}$ & $\begin{array}{l}88 \cdot 8 \\
(331)\end{array}$ & $\begin{array}{l}3 \cdot 2 \\
(12)\end{array}$ & - & $\begin{array}{l}5 \cdot 9 \\
(22)\end{array}$ & $\begin{array}{l}0 \cdot 8 \\
(3)\end{array}$ & $\begin{array}{l}1 \cdot 3 \\
(5)\end{array}$ & $\begin{array}{c}100 \\
(-373)\end{array}$ \\
\hline Totals & $\begin{array}{l}72 \cdot 8 \\
(331)\end{array}$ & $\begin{array}{l}10 \cdot 1 \\
(46)\end{array}$ & $\begin{array}{r}7 \cdot 0 \\
(32)\end{array}$ & $\begin{array}{l}6 \cdot 8 \\
(31)\end{array}$ & $\begin{array}{l}2 \cdot 0 \\
(9)\end{array}$ & $\begin{array}{l}1 \cdot 3 \\
(6)\end{array}$ & $\begin{array}{l}100 \\
(455)\end{array}$ \\
\hline $\begin{array}{l}\text { Females } \\
\text { Under } 60 \text { years }\end{array}$ & $\begin{array}{c}10 \cdot 8 \\
(4)\end{array}$ & $\begin{array}{l}29 \cdot 8 \\
(11)\end{array}$ & $\begin{array}{l}27 \cdot 0 \\
(10)\end{array}$ & $\begin{array}{l}8 \cdot 1 \\
(3)\end{array}$ & $\begin{array}{c}21 \cdot 6 \\
(8)\end{array}$ & $\begin{array}{l}2 \cdot 7 \\
(1)\end{array}$ & $\begin{array}{l}100 \\
(37)\end{array}$ \\
\hline $\begin{array}{l}60 \text { years and } \\
\text { over }\end{array}$ & $\begin{array}{l}89 \cdot 3 \\
(458)\end{array}$ & $\begin{array}{l}2 \cdot 7 \\
(14)\end{array}$ & - & $\begin{array}{l}5 \cdot 3 \\
(27)\end{array}$ & $\begin{array}{l}1 \cdot 7 \\
(9)\end{array}$ & $\begin{array}{l}1 \cdot 0 \\
(5)\end{array}$ & $\begin{array}{c}100 \\
(513)\end{array}$ \\
\hline Totals & $\begin{array}{l}84 \cdot 0 \\
(462)\end{array}$ & $\begin{array}{l}4 \cdot 5 \\
(25)\end{array}$ & $\begin{array}{l}1 \cdot 8 \\
(10)\end{array}$ & $\begin{array}{l}5 \cdot 5 \\
(30)\end{array}$ & $\begin{array}{l}3 \cdot 1 \\
(17)\end{array}$ & $\begin{array}{l}1 \cdot 1 \\
(6)\end{array}$ & $\begin{array}{c}100 \\
(550)\end{array}$ \\
\hline
\end{tabular}

* Private means and employment superannuation.

illiteracy, poor vision) to explain this fact, but no explanation was discovered for the inactivity of 26 men and 72 women.

(c) Frequency of Visits. - Table XIV records the frequency with which patients are visited. The proportion visited is remarkably high even after long periods in hospital, but 16 per cent. of men and 7 per cent. of women are never visited.

(d) Source of Income.-The information is given in Table XV. The most noteworthy feature of the table is the high proportion of persons below pensionable age who require the support of national assistance $(41.5$ per cent. of males and $29 \cdot 8$ per cent. of females).

\section{SUMMARY}

(1) In a hospital for the chronic sick, more than 90 per cent. of 1,005 patients were over 60 . This suggests that the usual expression of bed requirements as beds per thousand of the general population is unsatisfactory for this class of patient.

(2) Age specific rates were calculated for the chronic sick in Birmingham hospitals in December, 1948. The rate for persons over 65 was 12 per thousand of the population in this age group; in view of the known trend in age structure and of differences between different areas, this figure is more useful than the rate of 1.4 per thousand obtained for the Birmingham population at all ages. This figure cannot be used as an index of future requirements without reference to the possibility of reallocation of responsibility between Regional Hospital Boards and Local Authorities. 
(3) Although nearly half the beds in Western Road Infirmary were occupied by patients who had been in hospital over two years, 79 per cent. of the admissions of one year died or were discharged within four months. The data draw attention to the amount of acute illness treated in a hospital for the chronic sick.

(4) Comparison of the infirmary population with the general population of Birmingham (1931) and of Wolverhampton (1948) indicates that the marital status of patients has a considerable bearing on the possibility of their admission to or retention in hospital.

(5) More than two-thirds of the patients were admitted to hospital from their own homes or those of relatives. This fact makes it reasonable for Local Authorities to contemplate the provision of home services for many patients who need not be admitted to hospital.

(6) Only about half of the patients are willing to leave hospital if circumstances permit.

This research was assisted by a grant from the Birmingham University Students' Social Services' Fund. We have pleasure in acknowledging an indebtedness to Professor A. P. Thomson, who has contributed to this survey in many ways. The medical records were completed by Dr. Charmian Elkes, Dr. S. E. Hallissy, and Dr. P. M. Meynell, and the social records by Mrs. L. Leaver and Mrs. H. Pringle; the inquiry owes much to their work, and to the generous co-operation of Dr. Nagley and his staff at Western Road Infirmary. We are also indebted to Miss Frew, and to those other members of the almoner's department of the Birmingham United Hospitals who assisted in a preliminary pilot survey. The diagrams used in this paper were prepared by Miss C. Wall.

Affleck, J. W. (1947). Lancet, 1, 355.

REFERENCES

Lowe, C. R., and McKeown, T. (1949). British Journal of Social Medicine, 3, 110.

Ministry of Health (1945; 1946). " "Hospital Surveys." H.M.S.O., London.

M (1945). " "Hospital Survey for the London and Surrounding Areas." H.M.S.O., London.

Registrar-General England and Wales (1938). Decennial Supplement, England and Wales, 1931. H.M.S.O., London.

- (1948). Quarterly Return No. 400. H.M.S.O., London. H.M.S.O., London.

Sheldon, J. H. (1948). " The Social Medicine of Old Age." Nuffield Foundation, Oxford. 